\title{
IAMJ
}

INTERNATIONAL

AYURVEDIC

MEDICAL JOURNAL

Review Article

ISSN: 2320-5091

Impact Factor: 6.719

\section{THE ROLE OF MEDHYA RASAYANA IN THE MANAGEMENT OF MENTAL DISORDER}

\author{
Gupta Mohini $^{1}$, Bansal Harendra ${ }^{2}$, Sharma Shraddha $^{3}$, Sharma Vivek ${ }^{4}$ \\ ${ }^{1}$ Postgraduate (PG) Scholar, Department of Kayachikitsa, \\ ${ }^{2}$ Postgraduate (PG) Scholar, Department of Dravyaguna, \\ ${ }^{3}$ Assistant Professor, Department of Kayachikitsa, \\ ${ }^{4}$ Assistant Professor, Department of Kayachikitsa \\ Pt. Khushilal Sharma Govt. (Auto.) Ayurveda College and Institute, Bhopal (M.P.) India
}

Corresponding Author: mguever8@gmail.com

\section{https://doi.org/10.46607/iamj06p5052021}

(Published online: July 2021)

Open Access

(C) International Ayurvedic Medical Journal, India 2021

Article Received: 09/06/2021 - Peer Reviewed: 03/07/2021 - Accepted for Publication: 06/07/2021

\section{Check for updates}

\begin{abstract}
WHO has proposed that mental health is - ' A state of well-being in which the individual realizes his or her abilities can cope with the normal stresses of life, can work productively and fruitfully and can make a contribution to his or her community.' Mental disability has become one of the most dreadful conditions across the world. It is prevalent in almost every society and creates an enormous social and economic burden. Mental illness is characterized by disturbance in person, emotion, thoughts, or behaviour. The term mental illness (Mental behaviour) includes a wide variety of disorders, ranging from mild distress to severe impairment of social and occupational functioning. In 2017, 197.3 million people had mental disorders in India, including 45.7 million with depressive disorder and 44.9 million with anxiety disorder. A significant, but modest, correlation between the prevalence of depressive disorder and the suicide death rate at the state level for females and males. Medhya Rasayana affects the human psyche and mainly work at the level of neurotransmitters. Daily use of Medhya Rasayana is not only good for memory but also promotion of mental health. So, these media rasayan (Yashtimadhu, Guduchi, Shankhpushpi, Mandukaparni) drugs are effective in the treatment of mental disorders.
\end{abstract}

Keywords: Medhya, Rasayan, Anxiety, Neurotransmitters. 


\section{INTRODUCTION}

According to Ayurveda Satva (mind), Atma (soul) and Sharia(body) are three tripods of life, where the mind (Satva) occupies the first place, due to its importance in connecting the sentient soul with the nonsentient body.

As we know that all Medhya Rasayana work as nervine and brain tonic, therefore proper functioning of neurotransmitters should be done.

All mental disorders occur either due to the hyper or hypo functioning of neurotransmitters e.g. Low level of serotonin in depression, a dopamine deficiency can cause Parkinson's disease. Some common mental disorders are depression, anxiety, psychosis, bipolar disorders, schizophrenia, OCD etc.

WHO estimates that about 7.5 per cent of Indians suffer from some either mental disorder and predicts that by the end of the year 2020 roughly 20 per cent of India will suffer from mental illness. According to numbers 56 million Indians suffer from depression and another 38 million Indians suffer from anxiety disorders.

The WHO recognizes World Mental Health Day on $10^{\text {th }}$ October every year.

India also accounts for 36.6 per cent of suicides globally, as per the national mental health survey
2015- 16 conducted by the national institute of mental health and \& neuroscience (NIMHANS) Bengaluru, under the preview of the union ministry of health \& family welfare it was revealed that 9.8 million teenagers in the age group 13-17 years suffer from depression \& other mental health disorders and are " in need of active intervention.

In the present era, everyone prefers a treatment that is easily available, cost-effective and most important which has no or fewer side effects. Drugs commonly used in modern science for the treatment of mental disorders have hazardous side effects and have dose dependency. At the same time in Ayurveda, there are many pharmacological preparations available for the treatment of mental disorders.

\section{Medhya Rasayanas:-}

Medhya Rasayanas are a group of drugs described in Ayurveda with many benefits. Medha means intellect or retention and Rasayana which means curative or rejuvenating. Medhya Rasayanas help to enhance memory and concentration, creativity as well as brain activity.

Description of four Medhya Rasayan Yog is available in Charak Samhita $1^{\text {st }}$ Chapterrasayan (3 ${ }^{\text {rd }}$ pada, Karpratichiya Pada).

Table 1:

\begin{tabular}{|l|l|l|l|}
\hline S.No. & Drug & Botanical name & Part used \\
\hline $\mathbf{1}$ & Mandukaparni & Centella Asiatica & Whole plant juice \\
\hline $\mathbf{2}$ & Yashtimadhu or Mulethi & Glycyrrhiza glabra & Root powder \\
\hline $\mathbf{3}$ & Guduchi (giloy) & Tinospora cordifolia & Stem juice \\
\hline $\mathbf{4}$ & Shankhapushpi & Cocvolvulus Pleuricaulis & Whole plant paste \\
\hline
\end{tabular}

Few more drugs are used as Medhya Rasayana as described in different Ayurveda classical texts. They are Aindri (Bacopa monniera), Jyothishmati (Celestrus panniculatus), Kushmanda (Benincasa hispida), Vacha (Acorus calamus), Jatamansi (Nardostachys jatamansi).

Mental disorder: -

1. Anxiety disorder- Excessive fear and dread e.g.: - Phobias

2. Mood disorder- Persisting swing in mood or persisting feeling that interfere with daily life e.g.: depression, bipolar.

Depression is a mood disorder that can affect a person's daily life. It may be described as a feeling of sadness, loss or anger.

3. Psychotic disorder- Disordered thinking e.g.: Schizophrenia

4. Eating disorder- Extreme emotional attitudes toward food e.g.: - Bulimia, Anorexia.

5. Impulse disorder- Unable to resist urges e.g.: - 
Kleptomania, Pyromania, Gambling.

6. Personality disorder- Extremely inflexible personality traits e.g.: - Anti-social disorders, OCD.

7. Post-traumatic stress- Persistent, frightening memories leading to emotional numbness.

\section{Pathophysiology of mental disorder: -}

The brain contains millions of neurons each one interacting with others. The junction between two neurons is called a synapse. at the synaptic level, two neurons do not form an anatomical contact, but a small gap called the synaptic cleft. It brings about the release of neurotransmitters into the cleft.

The commonly seen neurotransmitters are-

1. Norepinephrine 2. Serotonin 3. Dopamine

These neurotransmitters do not remain active but are degraded by enzymes like NIAO-monoamine oxidase. one of the mechanisms by which these biological amines are protected from enzymatic action is, their re-uptake. The catabolic Enzyme does not have action on neurochemicals once they have gone back into vesicles.

So, in mental disorders, it is thus possible with unfavorable genetic factors in a person that he may have problems in producing adequate neurotransmitters.

Quantity of biogenic amines or may have poor reuptake into the vesicles, allowing greater destruction of neurotransmitters. This would make the person vulnerable to alteration in neurochemicals which would be triggered further by stress.

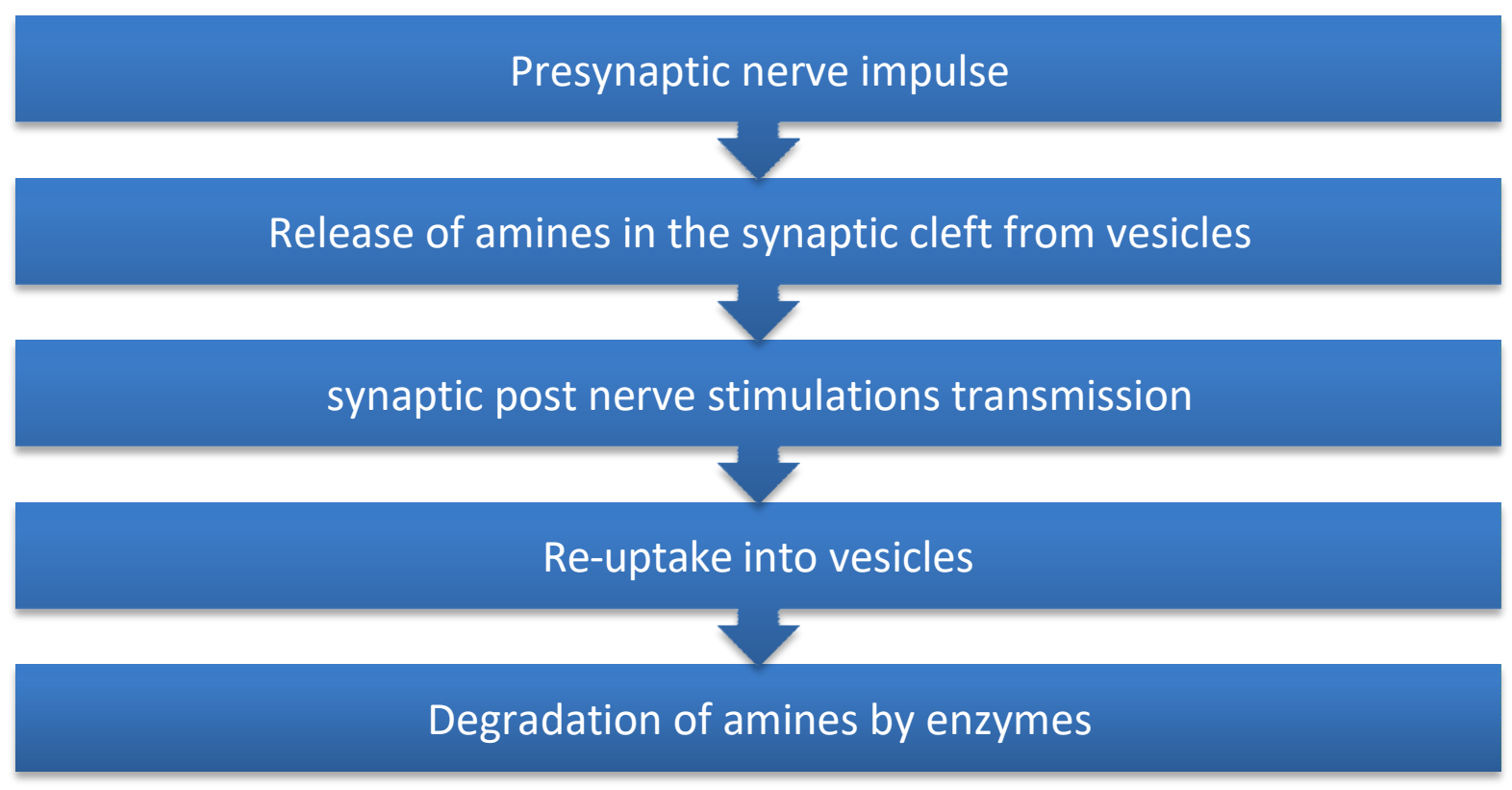

Table 2:

\begin{tabular}{|c|c|c|}
\hline S.No. & Neurotransmitters in the brain in mental disorder & Level \\
\hline 1. & Level of MAO (monoamine oxidase) & 1 \\
\hline 2. & Level of HVA - (Homovanillic acid) & $\sqrt{7}$ \\
\hline 3. & Level of catecholamine & $\sqrt{7}$ \\
\hline 4. & Level of dopamine & $\boldsymbol{7}$ \\
\hline 5. & Level of serotonin & $\sqrt{t}$ \\
\hline 6. & Level of acetylcholine & 1 \\
\hline 7. & Level of MHPG (methoxy-4 hydroxy phenylalycole) & $\sqrt{1}$ \\
\hline
\end{tabular}




\section{Mode of action of Medhya Rasayan on Mental dis- order}

Medhya Rasayana drugs have specific effects on mental health by promoting the functions of

Buddhi \& Manas by correcting the disturbance of Rajas \& Tamas.

\section{Mandukaparni-}

According to Ayurveda Mandukaparni is Medhya by Prabhava (Special effect). Mandukaparni present in Medhya Rasayana improves learning and memory process by modulating dopamine, 5hydroxytryptamine receptor and noradrenaline system.it reduces stress which is one of the leading factors of mental disorders. This may help in enhancing concentration power. An active principle present in Centella Asiatica imparts anxiolytic activity and thus, it helps in reducing Anxiety.

\section{Yashtimadhu}

The root of Glycorhiza glebra linn. (Yashtimadhu) contains the active principles, glycyrrhizin, glycoside, isoliquiritin, liquiritin, steroid estrogen, hispaglabridin B, isoliquiritigenin \& paratocarpin B. Experiments showed that Glycorhiza glebra linn. Increase blood circulation to the central nervous system \& balance the sugar level in the blood. Yashtimadhu have significant antioxidant activity. The antioxidants protect susceptible brain cells from oxidative stress resulting in reduced brain damage \& improved neuronal function, by enhancing memory.

\section{Guduchi}

Guduchi another component of Medhya Rasayana has Katu, Tikta rasas which help in keeping the mind alert by Tridoshahara property, it helps to establish a balance and good co-ordination of grasping retention. Tinospora cordifolia has active principles such as tinosporone, tinosporic acid, cordifolisides A-E, syringe, berberine giloin, gilenin \& glucan polysaccharide. The root extract of $T$. Cordifolia was found to possess normalizing activity against stress-induced changes in norepinephrine, dopamine 5hydroxytryptamine \& 5-hydroxy indoleacetic acid level. Guduchi antioxidant property helps in health promotion as well as preventive forthcoming disease.

\section{Shankhapushpi}

Shankhapushpi is the most effective among the four Medhya Rasayana drugs mentioned by Acharya Charaka. It has Kashaya rasa and Ushna guna, which may enhance the alertness and quick understanding and retention of experiences. It has Tridoshahara properties like- convolidine, confoline, phyllabine, subhirsine, and scopoline. These compounds help in brain stimulation and increase the ability to concentrate. $C$. pluricaulis reduces anxiety and stress by controlling the production of the body's stress hormones adrenaline and cortisol. It is reported to possess anxiolytic, memory enhancing, moodelevating effects and is claimed to retard brain ageing.

\section{DISCUSSION}

Mental disorders or mental illnesses are conditions that affect our thinking, feeling, mood and behaviour. They may be occasional or long-lasting (chronic) they can affect our ability to communicate with others and the proper functioning of the nervous system. Mental illness involves an imbalance of natural biochemicals in our brain \& body. They are associated with changes in neurotransmitters e.g.- In patients with depression, the level of neurotransmitters serotonin and dopamine is decreased.

In this study the effect of four Medhya rasayana Mandukaparni, Yashtimadhu, Guduchi and Shankhapushpi was studied. These are easily available and very effective in the treatment of mental disorders due to their nervine and brain tonic activities. It stimulates the secretion of neurotransmitters.

Medhya Rasayana drugs act on the Hypothalamuspituitary adrenal axis (HPA axis) \& normalize the secretion of neurotransmitters such as dopamine, serotonin, acetylcholine \& they can improve the mental functioning. These drugs promote intellect (Dhi), retention (Dhruti), memory (Smriti). 


\section{CONCLUSION}

Mental disorder (illness or behaviour) is a condition characterized by an alteration in the emotion's thoughts behaviour or psyche of an individual a compassing a wide variety of behavioural disorders.

In Ayurveda, a variety of drugs coined under the term Medhya Rasayana has been prescribed which functions at the level of neurotransmitters is act as a nervine tonic and promotes the functions of Buddhi and Manas by correcting the disturbance of Rajas and Tamas. The present study highlights the importance of making the Medhya Rasayana in the management of mental disorders.

\section{REFERENCES}

1. Agnivesha, Charaka, Dridhabala, Charaka Samhita, Chkitsa Sthana, Rasayana Adhyaya, Kara-Prachitiya Rasayana Pada, 1/3/30-31, Ayushi hindi commentary. In: Vd. Khushvaha HS, editor. 1st edition. Varanasi: Chaukhambha Orientalia Publisher; 2009. p. 30.

2. Effects of Medhya Rasayana and Yogic practices in improvement of short-term memory among schoolgoing children Atul Shankar Sarokte and Mangalagowri V. Rao.

3. Merikangas KR. Epidemiology of mental disorders in children and adolescents. Dialogues Clin Neurosci. 2009; 11:7-20

4. Sharan P. The need for National data on the epidemiology of child and adolescent mental disorders. J Indian Assoc Child Adolesc Mental Health. 2008; 4:22-7.

5. Wijeweera P, Arnason JT, Koszycki D, Merali Z. Evaluation of anxiolytic properties of Gotukola// (Centella Asiatica) extracts and asiaticoside in rat behavioural models. Phytomedicine. 2006; 13:668-76.

6. Reddy KY. Review on effect of natural memory enhancing drugs on dementia. Int J Phytopharm. 2010; $1: 1-7$.

7. Muralidharan P. Cerebroprotective effect of Glycyrrhiza glabra Linn root extract on a hypoxic rat. J Bangladesh Pharmacol Soc. 2009; 4:60-4.

8. Kokate CK. 29th ed. Pune: Nirali Publication; 2004. Textbook: Pharmacognosy; p. 164.

9. Vyas Shraddha, the thesis-clinical-comparative trial of Charakokta Medhya Rasayana in patients of Mansik avasad (Mental disorder).

10. Parmar Ashvin Kumar, thesis-A clinic-comparative study of Medhya Guduchyadi Rasayana and Shirodhara in the management of Avashada (Depression).

\section{Source of Support: Nil \\ Conflict of Interest: None Declared}

How to cite this URL: Gupta Mohini et al: The Role Of Medhya Rasayana In The Management Of Mental Disorder. International Ayurvedic Medical Journal \{online\} 2021 \{cited July, 2021\} Available from: http://www.iamj.in/posts/images/upload/2993_2997.pdf 